\title{
Developing a Mobile Game Using Scientific Approach to Support Mathematics Learning
}

\author{
Rhomiy Handican ${ }^{1, \text { a) }}$, Wahyu Setyaningrum ${ }^{2}$ \\ ${ }^{1}$ Institut Agama Islam Negeri Kerinci \\ Kapten Muradi Street, Sungai Liuk, Pesisir Bukit, Sungai Penuh, Jambi, Indonesia, 37152 \\ ${ }^{2}$ Universitas Negeri Yogyakarta \\ 1 Colombo Street, Caturtunggal, Depok, Sleman, Special District of Yogyakarta, Indonesia, 55281 \\ a)handicanrhomiy@gmail.com
}

\begin{abstract}
The widespread use of smartphones to play games and the lack of use as a medium for learning mathematics is the reason for the need for the development of smartphone-based edutainment learning media. The purpose of this research is to design and develop interactive edutainment learning applications of mobile mathematics games to help junior high school students to learn line and angles material. This mobile game-based application incorporates graphic design, background music, and animation, and a major structural element in game development to attract students. This research belongs to the type of Research and Development (R\&D) and the model used is the ADDIE model that is carried out in a systematic stage. The results of the study show that the developed game meets the valid aspects, where the level of expert approval of the design functionality has an average value of 4,49 out of 5, meanwhile, the assessment of the material has an average score of 4,17 out of 5 and the user states that the game meets the practical aspect with an average score of 3,75 out of 5 . It is hoped that this game-based learning application called "CORNER" for mobile devices can act as an additional tool for improving students' conceptual understanding and interest to learn through the scientific approach used.
\end{abstract}

Keywords: Andromatica; Edutainment; Mathematics Learning Media; Mobile Game; Scientific Approach

\begin{abstract}
Abstrak. Maraknya penggunaan smartphone untuk bermain game dan kurangnya pemanfaatan untuk digunakan sebagai media pembelajaran matematika menjadi alasan perlu adanya pengembangan media pembelajaran edutainment berbasis smartphone. Tujuan dari penelitian ini adalah merancang dan mengembangkan aplikasi pembelajaran edutainment interaktif game matematika mobile untuk membantu siswa SMP dalam mempelajari materi garis dan sudut. Aplikasi berbasis mobile game ini menggabungkan desain grafis, musik latar, dan animasi, dan merupakan elemen struktural utama dalam pengembangan game untuk menarik minat siswa. Penelitian ini termasuk jenis Research and Development (R\&D) dan Model yang digunakan adalah model ADDIE yang dilakukan dengan tahap yang sistematik. Hasil penelitian menunjukkan bahwa game yang dikembangkan memenuhi aspek valid, dimana tingkat persetujuan ahli terhadap fungsionalitas desain memiliki nilai rata-rata 4,49 dari 5 , sedangkan penilaian materi memiliki skor rata-rata 4,17 dari 5 dan pengguna menyatakan bahwa game memenuhi aspek praktis dengan skor rata-rata 3,75 dari 5. Diharapkan aplikasi pembelajaran berbasis game "CORNER" untuk perangkat mobile dapat berperan sebagai alat tambahan untuk meningkatkan pemahaman konseptual dan minat belajar siswa melalui pendekatan ilmiah yang digunakan.
\end{abstract}

Kata kunci: Andromatika; Edutainment; Media Pembelajaran Matematika; Mobile Game; Pendekatan Saintifik 


\section{INTRODUCTION}

Technology is essential in teaching and learning mathematics; it affects the mathematics that is taught and enhances student learning (NCTM, 2000). Technology supports the value of knowledge in the abstract phase as well as the value of usability in the concrete phase of the mathematical process, it changes the language of mathematics and causes a new quality of mathematical thinking (Heugl, 2004). The integration of technology in teaching becomes the challenge of $21^{\text {st-century }}$ education (Mukminan, 2014), so it is necessary to make educational technologies must expand their forward-thinking and competencies to ensure effective use of new technologies (Midgett $\&$ Eddins, 2001).

There are many ways to accept the education challenges of the 21 st century. One of them is by developing instructional media (Bourgonjon, Valcke, Soetaert, and Schellens, 2010), especially edutainment instructional media-based technology. Edutainment instructional media is perceived as a tool to improve the quality of teaching and learning (Burrill, Allison, Breaux, Kastberg, Leatham, and Sanchez, 2002). This is because technology has an influence on the development of mathematics in which the development of mathematics must be seen as a process that occurs in two phases, consisting of abstract and concrete phases (Heugl, 2004).

The edutainment approach gives students a good time and experiences their way of creating, using information resources and teaching methods. Game-based learning is an important topic in education in today's digital age as our digital society grows by adapting to multitasking in the hypermedia world and is no exception to learning mathematical concepts through games (Aksakal, 2015). A recent literature review concluded that interactive simulation and games were more effective than traditional classroom instruction on learners' cognitive gains (Bowers, 2006). It gives fresh air to the world of education that edutainment learning media can improve the quality of teaching, especially the ability to understand of material that is taught. However, needs further research in the mathematics field. But in designing it is necessary to understand how the characteristics of the game, the competition and the goals, the rules, the challenges, the choices are used in edutainment so that the game becomes effective and can influence motivation and facilitate learning (Charsky, 2010).

Gaming has evolved to be more than a medium of entertainment. Various platforms are being released and improved to be made available for the people. These can be used as a source of learning, fun, and entertainment. Games evolved from arcade to console, to PC (program computer), and now to mobile phones (Raimer, 2012). But if we see the number of education games genre, especially at the high school level is very rarely found either in google play store or in the app store. This is a consideration of researchers to develop a game that can be used as a medium that connects entertainment and education. This study aims to develop an interactive 
mobile game-based application in learning mathematics that could serve as a supplementary tool for students in learning line and angles material that would cater to the style preferences of today's generation with the scientific approach, so they can learn through the game that is fun rather than just told what to learn.

\section{METHOD}

This research includes the type of Research and Development (R \& D). R \& D method is a research method used to produce a particular product. The development of the game followed the ADDIE model that consists of analysis, design, development, implementation, and evaluation as the systematic stage (Branch, 2010). ADDIE method was used in the implementation of the study with the help of junior high school teachers and their students for the content and improvement of gameplay. The five phases or stages of the development are represented in Figure 1.

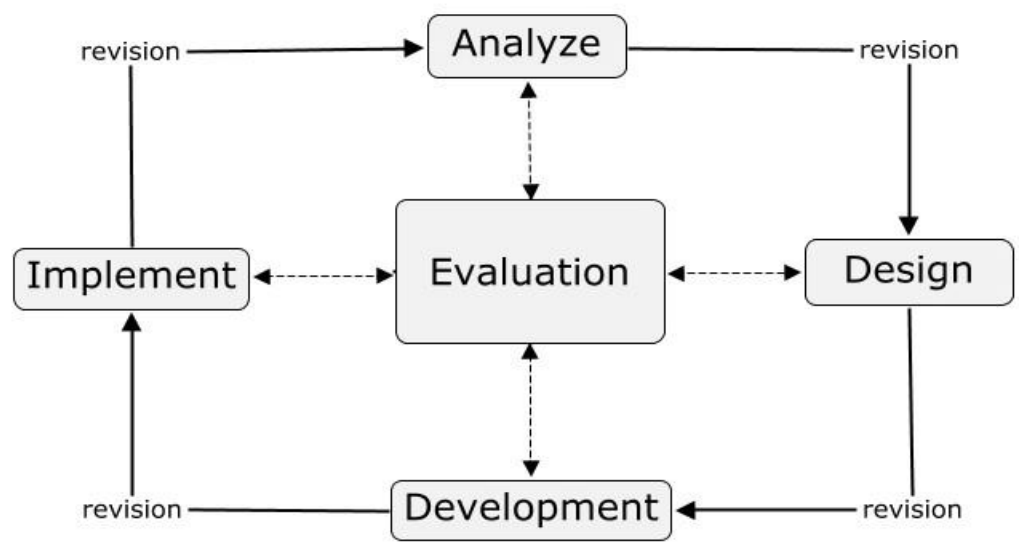

Figure 1. ADDIE Approach for Development of Game

\section{Analyze Phase}

At this stage an analysis of the need to develop learning media and the feasibility of development requirements. The purpose of the analysis phase is to identify the possible reasons for a learning implementation gap. General procedures in the analysis phase are needs analysis, curriculum analysis, analysis of student characteristics, resource analysis, and work plan analysis. This research attempted to design and develop an interactive and enjoyable way of learning mathematics that can serve as an additional tool for students learning about the lines and corners for the user target of junior high school students, especially for students aged eleven or twelve. The traditional way of teaching students about these topics is to provide books and classroom activities and these ways somehow make the students uninterested. For this reason, mobile game-based learning applications are conceptualized following the design principles presented in in-game literature that can help students learn while having fun. 


\section{Design Phase}

The design stage is intended to make the design of learning media based on smartphones. The general procedure of the design phase is as follows:

In the user design phase, the learning path selected for the mobile application is a scientific approach. In this approach, the student will only be able to progress through the game sequentially with scientific steps at every level of the game. Consequently, the learner can only go forward one way. The student can go back to the previous levels but is not allowed to skip around.

Figure 2 shows the functional decomposition diagram of the mobile application which includes a play button, how to play, and exit button while figure 3 shows the implementation of the main menu.

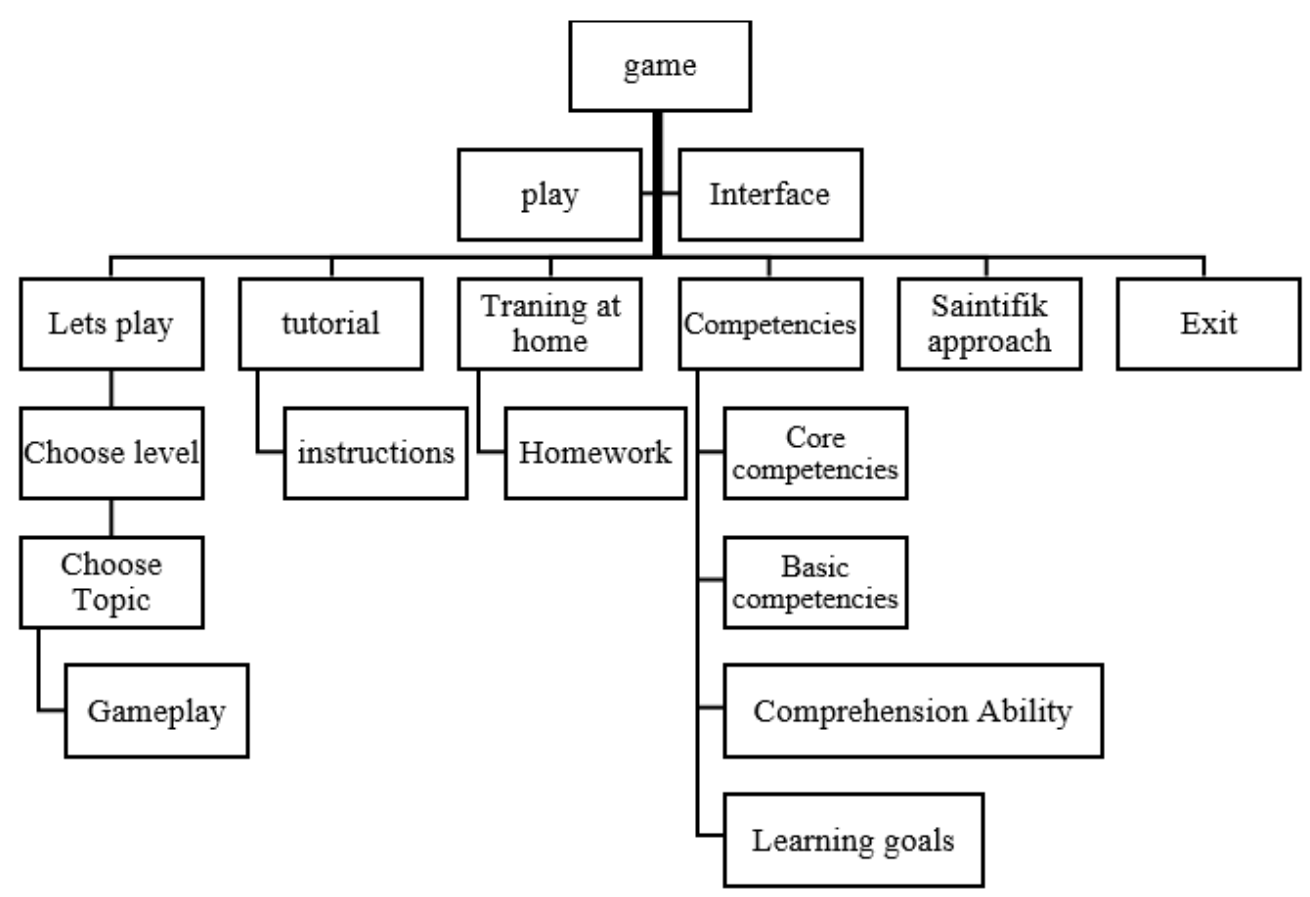

Figure 2. Functional Decomposition Diagram

Below are the functionalities of the mobile application:

The user can choose from the selected in the main interface and there are six options; let's play, game tutorial, training at home, basic competencies, scientific approach, and exit in the main interface. All of these can be seen in Figure 3. 


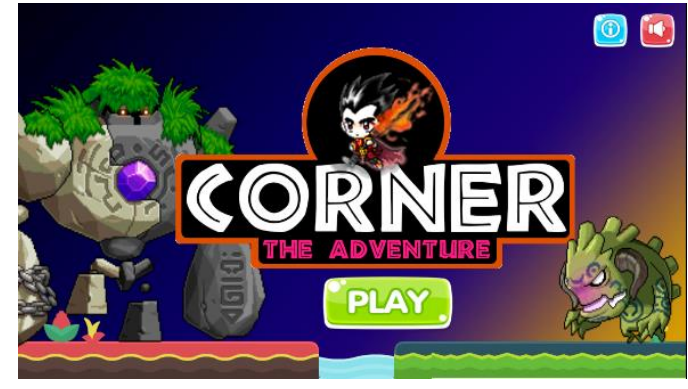

(a)

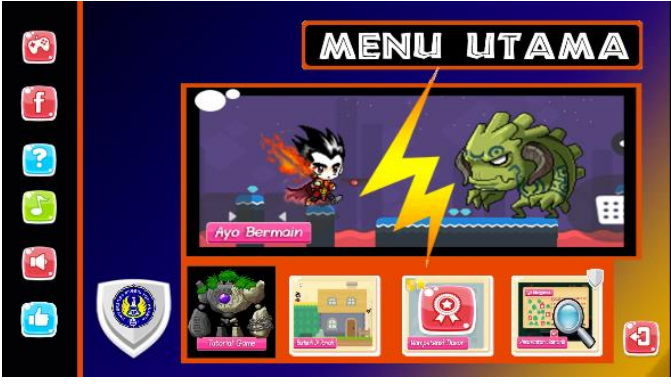

(b)

Figure 3. (a) Mainframe of the game, (b) Main Menu

In the lets play button in Figure 4, the user can choose a level game and the topics contain the five topics that the user can choose. The function of this menu is the user can easily select the material to be studied, the material presented is arranged systematically by the competencies expected by the curriculum.

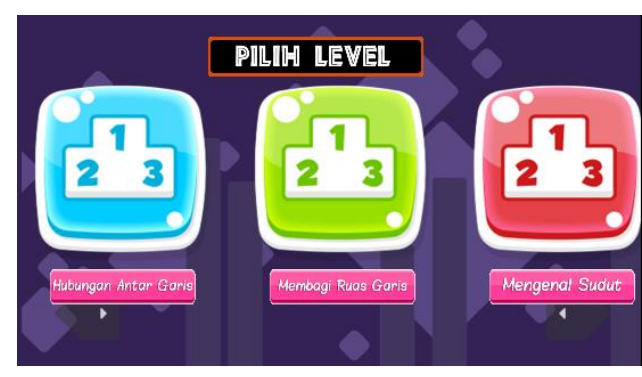

(a)

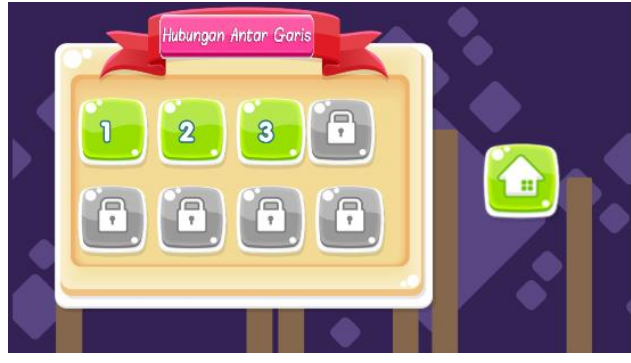

(b)

Figure 4. (a) Topic Options, (b) Level Options

In the gameplay, the player needs to look for a scientific approach to solve the mission. Figure 5 shows how CORNER directs to make observations and Figure 6 provides information that students must explore.

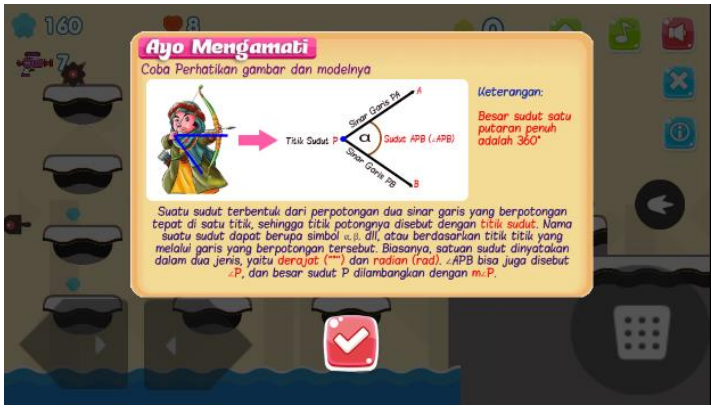

(a)

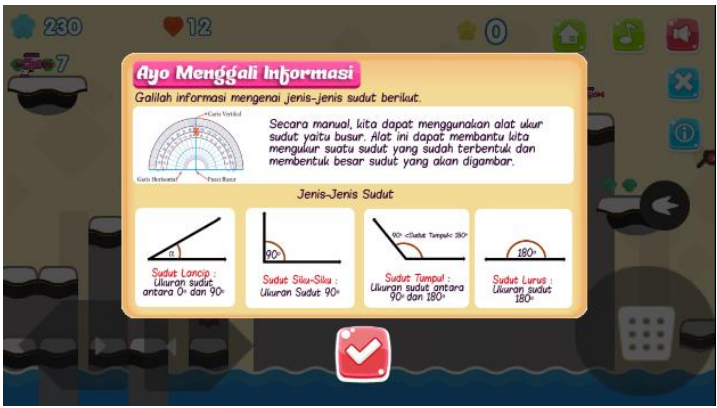

(b)

Figure 5. (a), (b) Views of The scientific Approach

Each topic has three stages and the last stage is the boss stage and the player cannot go to the next stage if they cannot solve the mission and must play from the beginning of the level. Figure 6 
is students faced with monsters that must be defeated and Figure 7 is how students complete the mission.

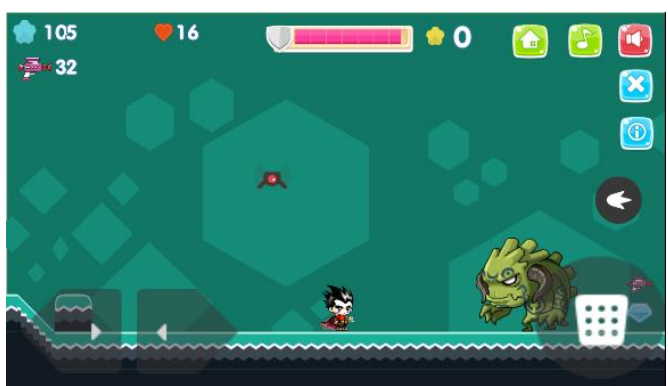

(a)

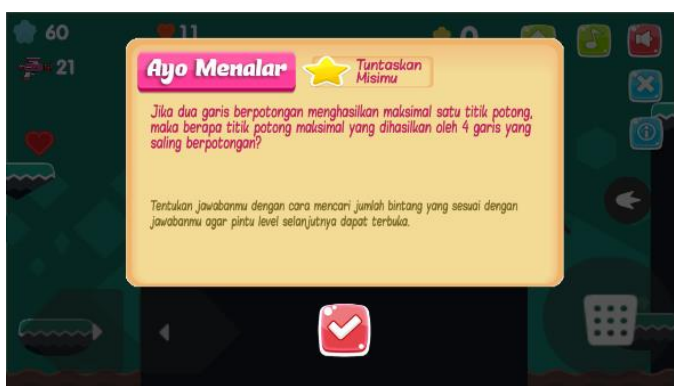

(b)

Figure 6. (a) Boss Stage and Mission of Game, (b) Mission of Game

When the player commits a mistake the heart would subtract from the character of the player. The main control of the game is by tapping the right and left buttons for character moves, fire button for shooting, and push-button for a jump.

To make the game more fun and interesting the following features have been added:

Each level has a different interface. Level 1 discusses the relationship of lines, dots, and fields, level 4 discusses how to split the line, level 7 discusses angles, and level 10 discusses the relationship between angles.
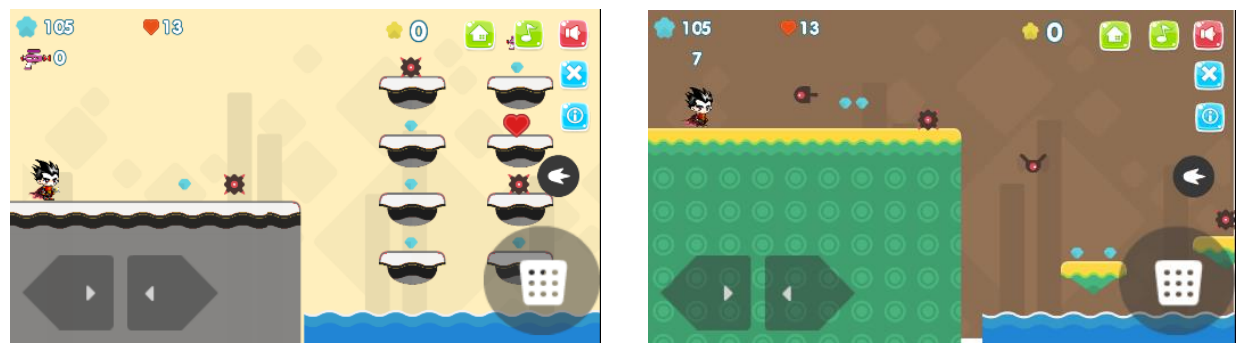

Figure 7. Display of Topics

Audio has been included but can be turned off or on, the game has an attractive appearance and color, and the letters and font used are simple and interesting.

\section{Development Phase}

The development of smartphone-based learning media products using Construct 2 software and adapted to the K13 curriculum. Learning media development results will be stored in the form of android applications. Step development includes activities to develop and modify learning media and product testing by way of testing. 


\section{One-to-One Trial Group}

Individual trials are conducted with individuals of varying ability levels and individuals who may have reason to participate in the research plan process. Individual trials in the designation to get initial feedback on instructional media. The subject of individual trials is the math teacher at the research school. game "Corner" is validated by four material experts and media with a given validation of media and material validation.

\section{Small Trial Group.}

The optimum number of small group trials is between 8 and 20, so in the small group trial, the trial subjects consist of 12 students of grade VII selected from low, moderate, and high-ability students. This trial serves to see early responses to games developed for early repairs. In general, the suggestion of the respondents is the game should be simplified and bugs contained in the game repaired again.

\section{Implementation Phase}

The purpose of the implementation phase is to prepare the learning environment and involve students in it. At the implementation stage, the product that has been tested is applied in real situations with actual teaching using a scientific approach.

At the implementation stage, the activities undertaken are as follows; (1) distribute instructional media applications to students that will be used in the pilot process, (2) explain to the student about the instruction of using android based learning media that will be used in learning, and (3) allow students to learn using learning media (researchers will assist students in learning and respond directly to feedback provided by students). It aims for the implementation of the road can run.

\section{Evaluation Phase}

The purpose of the evaluation phase is to assess the quality and process of the product. Evaluation is done at each stage. The Evaluation intended to improve the media at each stage, so that obtained a media that is appropriate for use in the learning process. Evaluation is done after the input obtained during the previous 4 stages. In addition, an evaluation phase is done in the form of evaluation of development and feasibility of learning media product to be tested.

A total of 34 students joined in the user acceptance testing and with the help of their teachers and three experts for analyzing the validity of the game. Forty-two items in the questionnaire were used to see the validity and thirty items on the material assessment questionnaire of the games 
evaluated by three experts in their field, fourteen items of student and teacher response questionnaires were used to see responses to games that had been built into APK.

A five-point Likert scale survey followed table 1 was developed and it contains the following criteria: media validity, learning content, and ease of use. Listed below are the questions asked from the respondents:

Design functionality. The product is valid if it meets the LORI indicator by Nesbit and Leacock that is; Content quality (Q1), Learning goal alignment (Q2), feedback (Q3), motivation (Q4), presentation design (Q5), interaction (Q6), accessibility (Q7), usability (Q8), standards compliance (Q9) (Leacock \& Nesbit, 2007).

Material Content. The quality of content and objectives, including accuracy, importance, completeness, balance, fairness, and conformity with student situations (Q10) and instructional qualities, including providing learning opportunities, providing learning assistance, motivating qualities, instructional flexibility, test quality, and assessment (Q11).

Practically. A product is said to be practically visible from the teacher and the student assumes that the product is attractive, easy to use under normal conditions, and the quality of media content with criteria: interest (Q12), and easy to use (Q13).

Table 1. Likert Scale Interpretation

\begin{tabular}{cc}
\hline Score & Verbal Interpretation \\
\hline 1 & Strongly disagree \\
\hline 2 & Disagree \\
\hline 3 & Neither Disagree or Agree \\
\hline 4 & Agree \\
\hline 5 & Strongly Agree \\
\hline
\end{tabular}

\section{RESULTS AND DISCUSSION}

Four tables are prepared: Table 2 shows the percentages per scale, Table 3 shows data validation results of media expert, Table 4 shows data validation results of content expert, and Table 5 shows media practicality assessment results. The data obtained was used to see the level of expert/validator/user approval against the game being developed. This was made so that the results can be described fully and issues can be identified for the improvement of the game. 
Table 2. Percentages Per Scale of The User Acceptance Results

\begin{tabular}{ccccccc}
\hline \multirow{2}{*}{ Criteria } & \multicolumn{1}{c}{$\mathbf{1}$} & $\mathbf{2}$ & $\mathbf{3}$ & $\mathbf{4}$ & $\mathbf{5}$ \\
\hline & $\mathrm{Q} 1$ & $0 \%$ & $0 \%$ & $4 \%$ & $32 \%$ & $4 \%$ \\
\cline { 2 - 7 } & $\mathrm{Q} 2$ & $0 \%$ & $0 \%$ & $0 \%$ & $88 \%$ & $13 \%$ \\
\cline { 2 - 7 } & $\mathrm{Q} 3$ & $0 \%$ & $0 \%$ & $0 \%$ & $25 \%$ & $75 \%$ \\
\cline { 2 - 7 } Design Functionality & $\mathrm{Q} 4$ & $0 \%$ & $0 \%$ & $0 \%$ & $25 \%$ & $75 \%$ \\
\cline { 2 - 7 } & $\mathrm{Q} 5$ & $0 \%$ & $0 \%$ & $0 \%$ & $37 \%$ & $63 \%$ \\
\cline { 2 - 7 } & $\mathrm{Q} 6$ & $0 \%$ & $0 \%$ & $0 \%$ & $37 \%$ & $63 \%$ \\
\cline { 2 - 7 } & $\mathrm{Q} 7$ & $0 \%$ & $0 \%$ & $0 \%$ & $40 \%$ & $60 \%$ \\
\cline { 2 - 7 } & $\mathrm{Q} 8$ & $0 \%$ & $0 \%$ & $0 \%$ & $0 \%$ & $100 \%$ \\
\hline \multirow{3}{*}{ Material Content } & $\mathrm{Q} 10$ & $0 \%$ & $0 \%$ & $0 \%$ & $72 \%$ & $28 \%$ \\
\cline { 2 - 7 } & $\mathrm{Q} 11$ & $0 \%$ & $0 \%$ & $0 \%$ & $93 \%$ & $7 \%$ \\
\hline \multirow{2}{*}{ Practically } & $\mathrm{Q} 12$ & $4 \%$ & $12 \%$ & $34 \%$ & $41 \%$ & $9 \%$ \\
\cline { 2 - 7 } & $\mathrm{Q} 13$ & $2 \%$ & $17 \%$ & $35 \%$ & $36 \%$ & $11 \%$ \\
\hline
\end{tabular}

In Table 2 and Table 3, under the first category of design function, almost all of the respondents strongly agree $(61 \%)$ with the appeal of the game and only a small percentage of users agreed $(32 \%)$ while half of the respondents agreed that the game had a good valid level, as well as less than ten percent, disagreed or agreed (4\%). So it can be concluded that the developed game design meets the criteria of validity $(4,7 / 5)$. This means that the developed game meets the necessary factors of edutainment-based media by Setyaningrum where a valid game is a game that has a good level of validity (Setyaningrum \& Waryanto, 2017).

Table 3. Data Validation Results By Media Expert

\begin{tabular}{cccc}
\hline Criteria & & Mean & Verbal Interpretation \\
\hline Content Quality & Q1 & 4,00 & Good/Agree \\
\hline Learning Goal Alignment & Q2 & 4,12 & Good/Agree \\
\hline Feedback & Q3 & 4,75 & Very Good/Strongly Agree \\
\hline Motivation & Q4 & 4,75 & Very Good/Strongly Agree \\
\hline Presentation Design & Q5 & 4,62 & Very Good/Strongly Agree \\
\hline Interaction & Q6 & 4,62 & Very Good/Strongly Agree \\
\hline Accessibility & Q7 & 4,60 & Very Good/Strongly Agree \\
\hline Usability & Q8 & 4,00 & Good/agree \\
\hline Standard Compliance & Q9 & 5,00 & Very Good/Strongly Agree
\end{tabular}

Further findings are known that from the aspects of feedback, motivation, presentation design, interaction, accessibility, and standard compliance, the average score of 4.7 out of 5 , which means that all the expert strongly agrees about these six aspects. This is following the criteria for a learning media to be said to be valid based on Branch, Gustafson, Nieven, and Plomp, where the product is said to be valid if the product developed is based on strong theoretical rationale and there 
is internal consistency between the components of the product being developed (Branch, Gustafson, Nieveen, \& Plomp, 1999).

In the second category in Table 2 and Table 4 , focusing on the material content of the game when asked about content quality almost half of the respondents agreed $(72 \% / 4,2)$ and almost half of the respondents strongly agreed (93\%/4) that the game could be useful and helpful in studying the lines and corners material. This data is under the research conducted by (Burrill et al., 2002) where edutainment media can improve the quality of learning. This is also in line with characteristics of an educational game development research results by Schmidt and Vandewater (2008), which shows that the game gives a significant effect to students less difficulty understanding the material, and students can repeat the material and improve students' activity (Oblinger, 2004).

Table 4. Data Validation Results By Content Expert

\begin{tabular}{cccc}
\hline Criteria & & Mean & Verbal Interpretation \\
\hline Quality of Content and Goals & Q10 & 4,28 & Good/Agree \\
\hline Instructional Quality & Q11 & 4,07 & Good/Agree \\
\hline
\end{tabular}

In practical terms from Table 5, although almost half of the respondents agree $(41 \% / 3,78)$, there is still thirty percent of respondents who disagree or agree with the games they are interested in which the games provided are interesting and easy-to-use games. This is in line with the results of the study that edutainment game media developed to help students learn mathematics to attract and arouse students' curiosity both the material learned and the game (Setyaningrum, 2016; Setyaningrum \& Waryanto, 2017). These findings are under the opinion of Charsky (2010) which states that for the development of a good edutainment game it is necessary to pay attention to the characteristics of a game, the characteristics are inherently and interdependent for each melds with others and all of them have the same overall goal, which is to motivate and excite the user.

Table 5. Media Practicality Assessment Results

\begin{tabular}{cccc}
\hline Criteria & & Mean & Verbal Interpretation \\
\hline Interest & Q12 & 3,78 & Good/Agree \\
\hline Easy of Use & Q13 & 3,72 & Good/Agree \\
\hline
\end{tabular}

\section{CONCLUSION}

Based on the results and analysis of the data collected from the users of the mobile game-based learning application the following can be concluded. In the design functionality, the aesthetics of the word infection game was successfully implemented as well as content quality, learning goal alignment, feedback, motivation, presentation design, interaction, accessibility, usability, standards 
compliance. However, the small percentage of users rating it as average must still be looked into for the improvement of the gameplay.

In the learning content, The quality of content and objectives, including accuracy, importance, completeness, balance, fairness, and conformity with student situations and instructional qualities, including providing learning opportunities, providing learning assistance, motivating qualities, instructional flexibility, test quality, and assessment was rated average and should be reviewed while the goal of making the mobile game application helpful and useful was successfully achieved.

In terms of practice, the design of the navigation of mobile games should be rechecked such as sizes of buttons and ways of moving backward and forward while the instruction provided has been successfully implemented. Overall, the mobile game-based learning application has been successfully implemented for junior high school students following the design principles provided regarding design functionality, learning content, and practically. Nevertheless, therefore, a limitation of this game is during the implementation in the classroom, the role of teachers to guide students to find the concept is still very necessary and teacher must have good classroom management skills because sometimes the game can cause noise.

Based on the results and the feedback from the users of the mobile game-based learning application the following are recommended. The demographics of students in the user acceptance should be included such as the level of technology use and the type of device they used for the game because navigation on the game can be affected by the size of the screen of the mobile phone they used. Include functionalities that can add more challenge and competition such as a module that records high scores, achievements to earn, a new model that is time-based. Besides the need for a checkpoint for the user does not to repeat too far when characters die or wrong answer questions. Lastly, combine a story that will make the game more relevant for students in junior high school and integrate other subjects in the story like character education that is also taught at the secondary level. It is also necessary to combine other teaching approaches or strategies with different materials.

\section{REFERENCES}

Aksakal, N. (2015). Theoretical View to The Approach of The Edutainment. Procedia - Social and Behavioral Sciences, 186, 1232-1239. https://doi.org/10.1016/j.sbspro.2015.04.081

Bourgonjon, J., Valcke, M., Soetaert, R., \& Schellens, T. (2010). Students' perceptions about the use of video games in the classroom. Computers \& Education, 54(4), 1145-1156. https://doi.org/10.1016/j.compedu.2009.10.022

Bowers, C. A. (2006). Computer Gaming and Interactive Simulations for Learning : A Meta-Analysis. May 2014. https://doi.org/10.2190/FLHV-K4WA-WPVQ-H0YM

Branch, R. M. (2010). Instructional Design : The ADDIE Approach. Springer. https://doi.org/10.1007/978-0- 
EDUMATIKA: Jurnal Riset Pendidikan Matematika

e-ISSN 2620-8911

Volume 2, Nomor 3, November 2020

p-ISSN 2620-8903

387-09506-6

Branch, R. M., Gustafson, K., Nieveen, N., \& Plomp, T. (1999). Design Approaches and Tools in Education and Training. In Design Approaches and Tools in Education and Training. Springer. https://doi.org/10.1007/978-94-011-4255-7

Burrill, G., Allison, J., Breaux, G., Kastberg, S., Leatham, K., \& Sanchez, W. (2002). Handheld Graphing Technology in Secondary Mathematics: Research Findings and Implications for Classroom Practice. 1-136. http://education.ti.com/sites/UK/downloads/pdf/References/Done/Burrill,G. (2002).pdf

Charsky, D. (2010). From Edutainment to Serious Games: A Change in the Use of Game Characteristics. Games and Culture, 5(2), 177-198. https://doi.org/10.1177/1555412009354727

Heugl, H. (2004). The influence of technology in several roles of mathematics. Austrian Center for Didactics of Computer Algebra, 1-35. http://www.acdca.ac.at/material/vortrag/montreal04.pdf

Leacock, T. L., \& Nesbit, J. C. (2007). A Framework for Evaluating the Quality of Multimedia Learning Resources. 10, 44-59.

Midgett, C. W., \& Eddins, S. K. (2001). NCTM's Principles and Standards for School Mathematics: Implications for Administrators. NASSP Bulletin, 85(623), 35-42. https://doi.org/10.1177/019263650108562305

Mukminan. (2014). Tantangan Pendidikan di Abad 21. Seminar Nasional Teknologi Pendidikan, 0-10.

NCTM. (2000). Principles and Standards for School Mathematics. School Science and Mathematics, 47(8), 868-279. https://doi.org/10.1111/j.1949-8594.2001.tb17957.x

Oblinger, D. G., \& Ph, D. (2004). The Next Generation of Educational Engagement Abstract: Keywords : 2004, 1-18.

Raimer, J. (2012). The Evolution of Video Gaming and Content Consumption. 1-24.

Schmidt, M. E., \& Vandewater, E. A. (2018). Media and Attention, Cognition, and School Achievement. $18(1)$.

Setyaningrum, W. (2016). Teachers' Perception Towards ICT in Mathematics Class: A case study in Yogyakarta Secondary Schools. May, 16-17.

Setyaningrum, W., \& Waryanto, N. H. (2017). Media Edutainment Segi Empat Berbasis Android: Apakah Membuat Belajar Matematika Lebih Menarik? 2(1), 40-56. 